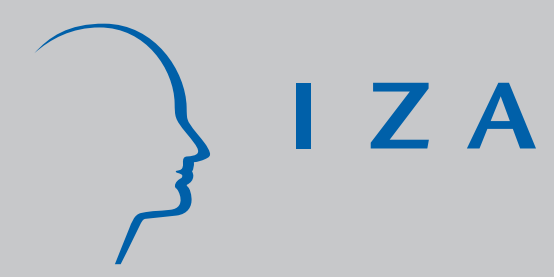

IZA DP No. 637

Household Labor Supply Effects of Low-Wage Subsidies in Germany

Holger Bonin

Wolfram Kempe

Hilmar Schneider

November 2002 


\title{
Household Labor Supply Effects of Low-Wage Subsidies in Germany
}

\author{
Holger Bonin \\ IZA Bonn
}

Wolfram Kempe

IZA Bonn

\section{Hilmar Schneider \\ IZA Bonn}

\section{Discussion Paper No. 637 \\ November 2002}

\author{
IZA \\ P.O. Box 7240 \\ D-53072 Bonn \\ Germany \\ Tel.: +49-228-3894-0 \\ Fax: +49-228-3894-210 \\ Email: iza@iza.org
}

This Discussion Paper is issued within the framework of IZA's research area Welfare State and Labor Market. Any opinions expressed here are those of the author(s) and not those of the institute. Research disseminated by IZA may include views on policy, but the institute itself takes no institutional policy positions.

The Institute for the Study of Labor (IZA) in Bonn is a local and virtual international research center and a place of communication between science, politics and business. IZA is an independent, nonprofit limited liability company (Gesellschaft mit beschränkter Haftung) supported by the Deutsche Post AG. The center is associated with the University of Bonn and offers a stimulating research environment through its research networks, research support, and visitors and doctoral programs. IZA engages in (i) original and internationally competitive research in all fields of labor economics, (ii) development of policy concepts, and (iii) dissemination of research results and concepts to the interested public. The current research program deals with (1) mobility and flexibility of labor, (2) internationalization of labor markets, (3) welfare state and labor market, (4) labor markets in transition countries, (5) the future of labor, (6) evaluation of labor market policies and projects and (7) general labor economics.

IZA Discussion Papers often represent preliminary work and are circulated to encourage discussion. Citation of such a paper should account for its provisional character. A revised version may be available on the IZA website (www.iza.org) or directly from the author. 
IZA Discussion Paper No. 637

November 2002

\section{ABSTRACT \\ Household Labor Supply Effects of Low-Wage Subsidies in Germany}

This research evaluates the impact on German household labor supply of various subsidy schemes proposed to foster low-wage employment. Using data from the German SocioEconomic Panel, we estimate a discrete choice model of household labor supply. On the basis of the estimated labor supply parameters of husbands and wives, we simulate participation and hours effects of different policies raising low labor earnings at the individual and household levels. In all cases, the labor supply effect is very moderate. Subsidies to individuals promote part-time employment, in particular of second earners, while subsidies based on low household income drive the better qualified partner out of the labor market so that the total number of labor market participants even declines.

JEL Classification: J68, J38, H24, J22

Keywords: low-wage subsidies, labor supply, discrete choice, Germany

Corresponding author:

Holger Bonin

IZA

P.O. Box 7240

D-53072 Bonn

Germany

Tel.: +49 2283894303

Fax: +492283893180

Email: bonin@iza.org 


\section{Introduction}

In Germany, unemployment has been increasing since the 1970s. This development has particularly affected the unskilled. At present, almost 40 percent of the unemployed are without formal qualification, which is far more than the share of the unqualified in the population. While skill-biased technological change seems to be reducing demand for unskilled labor worldwide, wages in Germany are too rigid downward at the bottom end to absorb the adverse employment impact of this process (Steiner/Mohr, 2000).

One explanation for lack of flexibility in the low-wage sector of the German labor market comes from provision of subsistence payments to the unemployed, generous by international standards, in conjunction with high implicit tax rates on labor earnings of transfer recipients. To give an example, the weekly net income of a single childless person working full-time who receives a gross wage of 7 Euros per hour, exceeds her claim on welfare benefits by only about 60 Euros. This comparison does not even consider any costs of working.

In order to overcome the labor supply disincentives of the German welfare state, reformers either could choose to cut effective benefits received during unemployment, or to increase households' in-work income. Decision makers mostly seem to prefer the latter. Several ways of lowering marginal transfer reduction rates or giving subsidies to low-wage earners have been proposed, and sometimes implemented on an experimental basis. Recently, policies to reduce 
payroll contributions to social insurance in the lower income range have become popular.

In this paper, we seek to evaluate the impact of different proposals to support low-qualified job seekers through subsidizing social insurance contributions. In particular, we evaluate what might be labeled the Mainzer, Stoiber and North Rhine-Westphalia (NRW) models. The latter two, proposed by conservatives and social democrats respectively, employ subsidy schemes based on individual earnings. In contrast, subsidies in the Mainzer model derive from the joint income of husbands and wives. To capture adequately the labor market effects of such an incentive scheme, we employ a model of joint household decisionmaking, which is estimated on the basis of data from the German Socio Economic Panel.

\section{Model, Data, and Estimation Results}

To explain individual labor supply, we use a static neoclassical structural model, which analyzes preferences in a household context. Spouses in two-adult families are assumed to maximize jointly a household utility function which depends on husband's and wife's leisure, and on household net income. Maximization is subject to a budget constraint including labor and non-labor income, and determined by the tax and benefits rules (e.g., Hausmann/Ruud, 1984). Following van Soest (1995), we limit the choice of the household's work hours to a discrete set of alternatives. The main advantage of the discrete choice approach is that it fa- 
cilitates estimation. The particular shape of the family budget set (nonconvexities etc.) does not affect numerical tractability.

To be specific, we assume that households with characteristics $X$ jointly maximize the family direct utility function $U\left(Y, H-h^{m}, H-h^{f} ; X\right)$, where $H$ represents individual total time endowment (set to 80 hours per week, for the empirical analysis), $h^{m}$ and $h^{f}$ male and female working time, and $Y$ net household income. Net income is a function of the two spouses' hourly wage rates, $w^{m}$ and $\mathrm{w}^{\mathrm{f}}$, working hours, and net taxes T, i.e., taxes paid minus transfers received by the household:

$$
Y=w^{m} h^{m}+w^{f} h^{f}-T\left(w^{m} h^{m}+w^{f} h^{f} ; X\right) .
$$

To discretize the choice set of the family, we assume that each individual can choose among only six alternatives of weekly working hours: $h^{i} \in\{0,10,20,30,40,50\}, i=m, f$. This yields a total of 36 choice opportunities for the two-adult household. We need to round working hours observed in the data, in order to fit the elements in the restricted choice set.

We estimate this model making two assumptions. First, we assume that the observed combination of the male and female partner's working hours is actually the utility maximizing one, conditional on the particular budget set of the household. Second, we add i.i.d. type I extreme value distributed random disturbances $v$ to the utilities associated with all choice opportunities. This leads to the familiar conditional logit model of qualitative choice behavior (McFadden, 1974). 
This model is easily estimated by maximum likelihood, if one ignores the fact that hourly wage rates for the non-employed are estimated rather than observed. For the empirical analysis, we use a translog specification of the direct utility function:

$$
U=x^{\prime} A x+b^{\prime} x+v
$$

where $x=\left(Y, H-h^{m}, H-h^{f}\right)^{\prime}, A$ is a symmetric $3 \times 3$ matrix of parameters, and $b$ a parameter vector $b=\left(b_{1}, b_{2}, b_{3}\right)$.

The translog specification implies that all possible interactions of male and female working hours and family net income are included in the estimation, as well as all elements of $x$ squared. Finally, to introduce observed heterogeneity among the households, we specify several parameters of the direct utility function as dependent on family characteristics $Z$, e.g., $b_{2}=\beta_{2}{ }^{\prime} Z$, with the intention of selecting the best among a large number of possible empirical specifications.

The data used in this analysis is from the 2000 wave of the German SocioEconomic Panel. We select two-adult households where both partners are older than age 18 and younger than age 60. After excluding households where at least one of the partners is retired, self-employed, a civil servant, in education or in military (national) service, or on parental leave, we are left with a total of 3702 couples, around 13 percent of which are unmarried but cohabiting. In 9.0 percent of the households, neither partner has a job, in 9.9 percent of the cases only the female partner is employed, and in 30.3 percent of the house- 
holds only the male partner works. We measure working time of the employed on the basis of regular working hours, which includes regular paid overtime.

To derive the household net income associated with each choice of male and female hours, we first predict potential hourly wages for the non-employed by a conventional selectivity-corrected wage regression (Heckman, 1979), using number of children and individual health status as exclusion restrictions. Gross wage rates are assumed to be independent of hours worked. In a second step, in order to obtain household net income for the feasible combinations of male and female partners' working time, a detailed but simplified model of the German tax and transfer system is applied. Specifically our fiscal model incorporates income taxation (including the solidarity surcharge), payroll contributions to social insurance, social welfare benefits, housing benefits, and child care benefits. The setting reflects the tax and transfer rules valid in year 2000 .

Table 1 displays the estimation results for our discrete choice model (model I) of household labor supply. The estimated parameters are hard to interpret directly, but they exhibit the expected signs. The coefficients of noninteracted male and female leisure $\left(\mathrm{I}^{\mathrm{m}}=\mathrm{H}-\mathrm{h}^{\mathrm{m}}\right.$ and $\left.\mathrm{I}^{\mathrm{f}}=\mathrm{H}-\mathrm{h}^{f}\right)$, as well as of household net income $\mathrm{Y}$, are positive and significant, whereas the coefficients of the squares of these variables are significantly negative. This indicates that the estimated direct utility function is well behaved in the sense that it increases at a declining rate in all its three arguments. 
Note also that female partners, especially those with children, value leisure more highly than male partners, which is consistent with the fact that in Germany women supply less labor, both in terms of participation rates and hours worked conditional on participation. Parameters of the interactions between male and female leisure are generally insignificant, suggesting that partners do not attempt to coordinate spare time.

While the results of our basic model I appear satisfactory, a simulation of the labor supply decisions implied by the estimated parameters reveals that the model is not very consistent with the data. Part-time is markedly over-predicted at the expense of full-time employment, perhaps a result of a lack of part-time jobs (Tummers/Woittiez, 1991). Thus, in model II, we adopt the strategy proposed by van Soest (1995), who corrects this problem by adding dummies for part-time choice opportunities to the regression. The estimated parameters of these dummies are all negative and highly significant. The parameters are less negative for women though, since they are employed part-time more frequently than men. In the estimated system of indifference curves, inclusion of part-time dummies generates a hump in the part-time range of working hours, which implies that optimal labor supply (given a budget constraint) is more frequent in the full-time range. The extended model fits the data quite well. A simulation using the utility parameters of model II predicts an average working time of 31.82 hours per week for male partners and 18.53 hours per week for female partners, compared to 32.06 and 18.49 hours, respectively, in the sample. 
For a first assessment of what effects on labor supply government might achieve by means of subsidizing in-work income, we present some earnings elasticities, based on the specification of model II. The simulations suppose a ten percent increase in the gross wage rate of each spouse, and in net household income, respectively. For the simulations, we first calculate, for each household, the probability of selecting a particular opportunity from the discrete choice set, as implied by the estimated coefficients of our model. We then compute participation rates as the sum of predicted probabilities characterized by positive working hours, whereas average hours are derived as the sum of predicted probabilities for every opportunity with positive working hours, times the hours value of the opportunity.

Table 2 shows that for each spouse, the own-wage elasticity regarding participation and hours worked is positive. It is larger for wives than for husbands. Male and female leisure are substitutes, since cross-labor wage elasticities are negative. Wives are more likely to withdraw from the labor market (or to reduce working hours) if the wage of their husband increases. Finally, a higher net household income does not significantly affect male labor supply, but, surprisingly, female working hours increase somewhat (as does participation to a lesser extent). In any case, the labor supply response to what are substantial changes in earnings is extremely small. Thus, one would not expect that wage subsidies could raise labor supply of the unemployed substantially.

\section{$3 \quad$ Policy Simulations}


In this section, we discuss the simulation results for different policies aimed at overcoming the labor supply disincentives of social subsistence payments to the unemployed, by improving in-work income of the less qualified through wage subsidies. The simulations proceed in the same fashion as the previous computation of wage and income elasticities: for each household, probabilities of selecting a specific hours combination as optimal are derived for each of the 36 choice opportunities, conditional on the budget set that becomes available to the household after policy reform. Participation rates are derived as the sum of predicted choice probabilities for opportunities with positive hours values. Average hours are the sample sum of predicted probabilities for each choice opportunity weighted by its hours value.

Although there are several proposals for government intervention to create a low-wage sector available, we limit this analysis to three proposals that have ranked high on the political agenda in Germany recently. Our first focus is on a proposal to phase in payroll contributions to social insurance only gradually at lower incomes. This scheme is supported by the conservative Christian Social Union, and is henceforth referred to as the Stoiber model, after their leader. The plan is to exempt monthly earnings of less than 400 Euro from contributions to social insurance, which lifts the current income bound by 75 Euro. Furthermore, in a phase-in region, contribution rates are planned to increase linearly, until the standard contribution rate (20.45 percent, for the employee) is reached at gross earnings of 800 Euro per month. 
The second policy to be analyzed, suggested by some social democrats (henceforth called the North Rhine-Westphalia (NRW) model, after the state where the concept was invented), is actually very similar, but more generous: the zone of contribution-free income is extended to 510 Euro, while the phase-in region, again characterized by linearly growing contribution rates, reaches up to monthly gross earnings of 1280 Euro.

The third policy model, the so-called Mainzer model, which was put into practice nationwide on March 1, 2002, is conceptually different from the previous two, because its subsidy scheme is based on household labor income rather than individual earnings. This means that the lower and upper bound of the phase-in region valid for singles are doubled for two-adult households, no matter how labor income is distributed between partners. Contributions to social insurance start at monthly earnings of 650 Euro. The full contribution rate, approached linearly, is hit at 1590 Euro. As a result, the policy covers a wider range of gross hourly wages, especially if the household adapts the one breadwinner model. Besides, the Mainzer model is also seen as a means of family friendly policy- households with children are entitled to an additional monthly benefit of up to 75 Euro per child. Its exact amount again depends on family labor income.

Table 3 summarizes the simulated impact of the three different policies on average hours worked, and on male and female participation rates. On the whole, the labor market impact of the subsidies is small. This is to be expected 
considering the rather small wage and income elasticities obtained from the estimated model parameters. The startling result is that general subsidization of low monthly incomes reduces aggregate labor supply. The more generous of the two individual subsidy models lowers the average working hours of men, compared to the baseline simulation, by 0.3 percent.

The Mainzer model, in the variant including the extra payment for children, brings average male working hours down by almost 1.3 percent. At the same time, the volume of female labor supply stays basically unchanged. This reveals that the subsidy does not only create an incentive for low qualified agents to expand their labor supply, but at the same time also an incentive for better qualified household members to reduce work to part-time. The associated earnings loss is partly compensated by the subsidy, while additional utility is drawn from more leisure. It turns out that for men, in the aggregate, this effect dominates the calculated impact of the subsidy, but it is also important for women.

In all scenarios the number of no-earner households declines. This response is strongest for the NRW model, which reduces the number of no-earner households by 3.5 percent. Since women receive lower wages in general, they benefit from the subsidy more frequently than men- all policies raise the share of households in which the female partner is employed. Still, the policies affect the allocation of work within the household differently.

This is best seen comparing the Stoiber and the Mainzer models, either of which raises the share of households with employed females close to 61.3 per- 
cent (up from 60.9 percent in the baseline simulation). However, while the former attracts female (second) earners so that the number of two earner households increases at the expense of the male breadwinner model, the latter puts women into full-time work. In the consequence, male earners withdraw from the labor market so that the two-earner type of household becomes less frequent. This is to the benefit of the rather unusual female breadwinner model, which gains by 10.2 percent. The explanation is that the Mainzer model, unlike the Stoiber and the NRW models, reaches well into the full-time range, provided that the partners decide to specialize on market and home production, respectively. Then the drift from male to female labor, as explained, is due to the gender wage rate differential.

The previous observation matters for the aggregate participation effects of the different subsidy concepts, on display in Table 4. To provide more illustrative figures, we blow up the sample using the household weights provided with the data. The gender wage rate effect is obviously present for all policies. It makes the small participation success of the individual subsidy strategies even smaller. In aggregate terms, the Stoiber model induces only 26,000 people to enter the workforce, a negligible number relative to the 4.4 million non-employed represented by our sample. The more generous (and much more costly) NRW model, with a gain in participation of 64,900 agents, is also hardly a success. The Mainzer model is even destructive- aggregate participation falls by a number of 29,000 or 43,300 , depending on whether extra child benefits are paid, due to the strong negative participation effect on males associated with the policy. 
Our simulation results should be viewed somewhat cautiously, since misspecification might be a problem. For example, we have neglected the fixed costs of working and ignored the stochastic nature of the auxiliary wage rate predictions. Besides, we lack sufficient variables on household wealth. Moreover, our simulation technique, based on predicted choice probabilities, is perhaps inadequate, as conceptually the discrete choice model would require applying a maximum probability approach. This alternative is much harder to compute, however, since one has to respect the probabilistic nature of the individual optimal choice (Duncan/Weeks, 1998).

\section{Conclusions}

Overall, policies aimed at improving in-work income for the unskilled by reducing the labor supply disincentives emanating from the German welfare system do not appear to be very effective. The reason for this is that the empirical wage elasticity of labor supply, as measured in this analysis, is very small. Therefore, subsidy policies that have a substantial labor market impact are probably too costly to finance.

Moreover, subsidies at low labor incomes might have accidental side effects. Since male and female leisure are substitutes, there is a tendency for husbands to reduce their labor supply, to the benefit of wives whose lower earnings capacity makes it easier for them to get into reach of the wage subsidy. If the subsidized income range becomes wide enough, this might even reduce ag- 
gregate participation. The specific policies studied in this research also appear to be fiscally inefficient. Basing the subsidy on low monthly earnings rather than low hourly wages creates strong part-time incentives beyond the target group of the low qualified. Besides, individuals who were already employed before the policy is introduced take up the vast majority of the subsidy, if it is paid to everybody at low income.

In view of the obstacles to cure the consequences of the disincentives for unqualified labor, decision makers might be well advised to engage in reforms that target the causes of the low-wage employment problem in the welfare system instead. It appears that workfare concepts are at the horizon also in Germany. 


\section{References}

Duncan, A. / M. Weeks (1998), Simulating Transition Probabilities using Discrete Choice Models, Proceedings of the American Statistical Association 106, 151-156.

Hausmann, J. / P. Ruud (1984), Family Labor Supply with Taxes, American Economic Review 74, 242-248.

Heckman, J. (1979), Sample Selection Bias as a Specification Error, Econometrica $47,153-161$.

McFadden, D. (1974), Conditional Logit Analysis of Qualitative Choice Behavior, in: P. Zarembka, Frontiers in Economics, New York.

Steiner, V. / R. Mohr (2000), Industrial Change, Stability of Relative Earnings, and Substitution of Unskilled Labor in West Germany, in: W. Salverda / B. Nolan / C. Lucifora (eds.), Policy Measures for Low-Wage Employment, Aldershot.

Tummers, M. / I. Woittiez (1991), A Simultaneous Wage and Labor Supply Model with Hours Restrictions, Journal of Human Resources 26, 393-423.

van Soest, A., Structural Models of Family Labor Supply, A Discrete Choice Approach, Journal of Human Resources 30, 63-87. 
Table 1: Estimation results of structural model - working hour choice of male and female partner

\begin{tabular}{|c|c|c|c|c|}
\hline & \multicolumn{2}{|c|}{$\begin{array}{c}\text { Model I } \\
\text { No part-time correction }\end{array}$} & \multicolumn{2}{|c|}{$\begin{array}{c}\text { Model II } \\
\text { Part-time Correction }\end{array}$} \\
\hline & Parameter & t-value & Parameter & t-value \\
\hline$(\log Y)^{2}$ & $-0.37^{* *}$ & -1.97 & $-1.49^{* * *}$ & -7.53 \\
\hline$(\log Y) \times\left(\log I^{m}\right)$ & $-0.58^{* * *}$ & -3.20 & $-1.01^{* \star *}$ & -5.91 \\
\hline$(\log Y) \times\left(\log I^{f}\right)$ & $-0.73^{* * *}$ & -4.33 & $-1.19^{* * *}$ & -7.38 \\
\hline$(\log Y)$ & $19.49^{* * *}$ & 3.91 & $44.75^{\star \star \star}$ & 9.13 \\
\hline$\left(\log \mathrm{I}^{\mathrm{m}}\right)^{2}$ & $-3.98^{* * *}$ & -14.63 & $-10.88^{* * *}$ & -34.00 \\
\hline$\left(\log \mathrm{I}^{f}\right)^{2}$ & $-1.52^{\star \star *}$ & -5.67 & $-14.89^{\star * *}$ & -19.20 \\
\hline$\left(\log I^{m}\right) \times\left(\log I^{f}\right)$ & 2.23 & 1.01 & 1.62 & 0.76 \\
\hline x Age & -1.05 & -0.85 & -0.97 & -0.83 \\
\hline$x \mathrm{Age}^{2}$ & 0.15 & 0.88 & 0.14 & 0.87 \\
\hline$x$ Children younger than 3 & $-0.37^{* * *}$ & -2.93 & $-0.34^{* * *}$ & -2.82 \\
\hline x Children older than 3 & -0.22 & -0.69 & -0.22 & -0.83 \\
\hline x East German & $0.39^{*}$ & 1.78 & $0.52^{* *}$ & 2.26 \\
\hline x Married & -0.41 & -1.49 & -0.36 & -1.21 \\
\hline$\left(\log I^{m}\right)$ & $108.48^{* * *}$ & 5.11 & $171.56^{* * *}$ & 8.50 \\
\hline x Age & $-18.39^{* * *}$ & -3.60 & $-38.05^{\star * *}$ & -3.58 \\
\hline$x \mathrm{Age}^{2}$ & $5.74^{* * *}$ & 3.76 & $5.43^{* * *}$ & 3.76 \\
\hline$x$ Children younger than 3 & $3.01^{* * *}$ & 2.84 & $2.62^{* * *}$ & 2.62 \\
\hline x Children older than 3 & 2.09 & 0.78 & 2.05 & 0.90 \\
\hline x East German & $-3.30^{*}$ & -1.86 & $-4.37^{* *}$ & -2.34 \\
\hline x Married & 2.68 & 1.23 & 2.21 & 0.93 \\
\hline x Care & 0.13 & 0.31 & 0.11 & 0.27 \\
\hline x Poor Health & $1.80^{* * *}$ & 6.36 & $1.44^{\star * *}$ & 6.08 \\
\hline$\left(\log I^{f}\right)$ & $135.05^{\star * *}$ & 5.76 & $255.35^{\star \star *}$ & 10.68 \\
\hline x Age & $-65.56^{* * *}$ & 5.34 & $-66.69^{* * *}$ & -5.30 \\
\hline$x$ Age $^{2}$ & $9.44^{* * *}$ & 4.36 & $9.57^{* * *}$ & 5.51 \\
\hline$x$ Children younger than 3 & $4.23^{* * *}$ & 4.36 & $3.88^{* * *}$ & 4.21 \\
\hline$x$ Children older than 3 & $5.12^{* *}$ & 2.14 & $4.53^{* * *}$ & 2.22 \\
\hline x East German & $-5.30^{* * *}$ & -3.13 & $-6.28^{* * *}$ & -3.50 \\
\hline x Married & $4.10^{* *}$ & 1.94 & $4.05^{\star}$ & 1.75 \\
\hline x Care & $1.94^{* * *}$ & 3.40 & $1.60^{* * *}$ & 3.25 \\
\hline x Poor Health & 0.49 & 1.46 & 0.46 & 1.44 \\
\hline \multicolumn{5}{|l|}{ Part-Time Indicators } \\
\hline$h^{m}=10$ & & & $-4.37^{* * *}$ & -21.93 \\
\hline$h^{m}=20$ & & & $-5.30^{* * *}$ & -23.46 \\
\hline$h^{m}=30$ & & & $-3.10^{* * *}$ & -41.46 \\
\hline$h^{f}=10$ & & & $-2.65^{* * *}$ & -30.65 \\
\hline$h^{f}=20$ & & & $-2.48^{* * *}$ & -24.19 \\
\hline $\mathrm{h}^{\mathrm{f}}=30$ & & & $-2.51^{* * *}$ & -25.13 \\
\hline Pseudo- $R^{2}$ & \multicolumn{2}{|c|}{0.1358} & \multicolumn{2}{|c|}{0.3939} \\
\hline
\end{tabular}

Notes: Conditional logit for the couple's choice of male and female working hours combination. There are 36 possible combinations. The sample size is 3702 couples. $Y$ is the net household income associated with the choice, $I^{\mathrm{m}}$ and $\mathrm{I}^{\mathrm{f}}$ are the leisure associated with the choice for the male and the female, and the part-time indicators are a set of dummies indicating whether the choice is one where one of the partners works part-time. ${ }^{* * *}$ indicates parameter is significant at the one percent level; ${ }^{* *}$ indicates parameter is significant at the five percent level; * indicates parameter is significant at the ten percent level. 
Table 2: Simulated labor supply elasticities (Model II)

\begin{tabular}{|c|c|c|c|c|c|c|}
\hline & \multicolumn{2}{|c|}{ Male Wage Rate } & \multicolumn{2}{|c|}{ Female Wage Rate } & \multicolumn{2}{|c|}{ Household Net Income } \\
\hline & $\begin{array}{l}\text { Hours } \\
\text { Worked }\end{array}$ & Participation & $\begin{array}{l}\text { Hours } \\
\text { Worked }\end{array}$ & Participation & $\begin{array}{l}\text { Hours } \\
\text { Worked }\end{array}$ & Participation \\
\hline $\begin{array}{l}\text { Male } \\
\text { Labor }\end{array}$ & 0.021 & 0.019 & -0.002 & -0.002 & 0.001 & 0.000 \\
\hline $\begin{array}{l}\text { Female } \\
\text { Labor }\end{array}$ & -0.003 & -0.003 & 0.027 & 0.020 & 0.015 & 0.009 \\
\hline
\end{tabular}

Note: Percentage response to 10 percent increase in gross hourly wage rates, or net household income.

Table 3: Simulated labor supply responses to different low-wage subsidy policies (Model II)

\begin{tabular}{|c|c|c|c|c|c|c|}
\hline & \multicolumn{2}{|c|}{ Average Hours } & \multicolumn{4}{|c|}{ Participation Rates } \\
\hline & Males & Females & $\begin{array}{c}h_{m}=0 \\
h_{f}=0\end{array}$ & $\begin{array}{c}h_{m}=0 \\
h_{f}>0\end{array}$ & $\begin{array}{c}\mathrm{h}_{\mathrm{m}}>0 \\
\mathrm{~h}_{\mathrm{f}}=0\end{array}$ & $\begin{array}{l}h_{m}>0 \\
h_{f}>0\end{array}$ \\
\hline Sample & 32.06 & 18.49 & 8.97 & 9.91 & 30.31 & 50.81 \\
\hline Baseline Simulation & 31.82 & 18.53 & 8.48 & 10.86 & 30.63 & 50.03 \\
\hline Stoiber Model & 31.79 & 18.50 & 8.37 & 10.99 & 30.36 & 50.27 \\
\hline NRW Model & 31.72 & 18.57 & 8.18 & 11.26 & 29.96 & 50.59 \\
\hline \multicolumn{7}{|l|}{ Mainzer Model } \\
\hline - Contribution Subsidy & 31.48 & 18.52 & 8.29 & 11.83 & 30.52 & 49.35 \\
\hline $\begin{array}{l}\text { - Contribution Subsidy } \\
\text { + Child Support }\end{array}$ & 31.42 & 18.53 & 8.27 & 11.97 & 30.50 & 49.27 \\
\hline
\end{tabular}


Table 4: Simulated aggregate change in number of labor force participants (Model II)

\begin{tabular}{lccc}
\hline & Males & Females & Net Effect \\
\hline Stoiber Model & $-2,599$ & 28,625 & 26,026 \\
NRW Model & $-10,929$ & 75,756 & 64,872 \\
Mainzer Model & & & \\
- Contribution Subsidy & $-63,550$ & 24,513 & $-29,037$ \\
$\begin{array}{l}\text { - Contribution Subsidy } \\
\quad \text { Child Support }\end{array}$ & $-62,172$ & 28,969 & $-43,203$ \\
\hline
\end{tabular}

Note: Change in number of participants relative to baseline simulation; computed using weights taken from GSOEP. 


\section{IZA Discussion Papers}

\begin{tabular}{|c|c|c|c|c|}
\hline No. & Author(s) & Title & Area & Date \\
\hline 621 & G. Saint-Paul & On Market Forces and Human Evolution & 5 & $11 / 02$ \\
\hline 622 & $\begin{array}{l}\text { J. Hassler } \\
\text { J. V. Rodriguez Mora }\end{array}$ & Should UI Benefits Really Fall Over Time? & 3 & $11 / 02$ \\
\hline 623 & $\begin{array}{l}\text { A. R. Cardoso } \\
\text { P. Ferreira }\end{array}$ & $\begin{array}{l}\text { The Dynamics of Job Creation and Destruction } \\
\text { for University Graduates: Why a Rising } \\
\text { Unemployment Rate Can Be Misleading }\end{array}$ & 1 & $11 / 02$ \\
\hline 624 & $\begin{array}{l}\text { J. Wagner } \\
\text { R. Sternberg }\end{array}$ & $\begin{array}{l}\text { Personal and Regional Determinants of } \\
\text { Entrepreneurial Activities: Empirical Evidence } \\
\text { from the REM Germany }\end{array}$ & 1 & $11 / 02$ \\
\hline 625 & F. Galindo-Rueda & $\begin{array}{l}\text { Endogenous Wage and Capital Dispersion, On- } \\
\text { the-Job Search and the Matching Technology }\end{array}$ & 3 & $11 / 02$ \\
\hline 626 & A. Kunze & $\begin{array}{l}\text { Gender Differences in Entry Wages and Early } \\
\text { Career Wages }\end{array}$ & 5 & $11 / 02$ \\
\hline 627 & $\begin{array}{l}\text { J. Boone } \\
\text { J. C. van Ours }\end{array}$ & Cyclical Fluctuations in Workplace Accidents & 5 & $11 / 02$ \\
\hline 628 & $\begin{array}{l}\text { R. Breunig } \\
\text { D. A. Cobb-Clark } \\
\text { Y. Dunlop } \\
\text { M. Terrill }\end{array}$ & $\begin{array}{l}\text { Assisting the Long-Term Unemployed: Results } \\
\text { from a Randomized Trial }\end{array}$ & 6 & $11 / 02$ \\
\hline 629 & $\begin{array}{l}\text { I. N. Gang } \\
\text { K. Sen } \\
\text { M.-S. Yun }\end{array}$ & Caste, Ethnicity and Poverty in Rural India & 2 & $11 / 02$ \\
\hline 630 & W. Arulampalam & $\begin{array}{l}\text { State Dependence in Unemployment Incidence: } \\
\text { Evidence for British Men Revisited }\end{array}$ & 3 & $11 / 02$ \\
\hline 631 & $\begin{array}{l}\text { H. O. Duleep } \\
\text { M. Regets }\end{array}$ & $\begin{array}{l}\text { The Elusive Concept of Immigrant Quality: } \\
\text { Evidence from 1970-1990 }\end{array}$ & 1 & $11 / 02$ \\
\hline 632 & $\begin{array}{l}\text { B. Cockx } \\
\text { M. Dejemeppe }\end{array}$ & $\begin{array}{l}\text { Duration Dependence in the Exit Rate out of } \\
\text { Unemployment in Belgium: Is It True or } \\
\text { Spurious? }\end{array}$ & 2 & $11 / 02$ \\
\hline 633 & A. D. Kugler & Employee Referrals and Efficiency Wages & 5 & $11 / 02$ \\
\hline 634 & $\begin{array}{l}\text { A. D. Kugler } \\
\text { R. M. Sauer }\end{array}$ & $\begin{array}{l}\text { Doctors Without Borders: The Returns to an } \\
\text { Occupational License for Soviet Immigrant } \\
\text { Physicians in Israel }\end{array}$ & 1 & $11 / 02$ \\
\hline 635 & $\begin{array}{l}\text { M. Karanassou } \\
\text { D. J. Snower }\end{array}$ & An Anatomy of the Phillips Curve & 3 & $11 / 02$ \\
\hline 636 & $\begin{array}{l}\text { M. Karanassou } \\
\text { H. Sala } \\
\text { D. J. Snower }\end{array}$ & $\begin{array}{l}\text { A Reappraisal of the Inflation-Unemployment } \\
\text { Tradeoff }\end{array}$ & 3 & $11 / 02$ \\
\hline 637 & $\begin{array}{l}\text { H. Bonin } \\
\text { W. Kempe } \\
\text { H. Schneider }\end{array}$ & $\begin{array}{l}\text { Household Labor Supply Effects of Low-Wage } \\
\text { Subsidies in Germany }\end{array}$ & 3 & $11 / 02$ \\
\hline
\end{tabular}

An updated list of IZA Discussion Papers is available on the center's homepage www.iza.org. 